\title{
References:
}

1. Быстрица Р.А. Репродуктивная функция у больных хроническим абактериальным простатитом. Здоровье мужчины. 2016. № 2 (57). C. $121-122$.

2. Горбачев А.Г., Тюрин А.Г. Лечение острого и хронического простатита пептидным препаратом из предстательной железы в эксперименте Урол. ведомости. 2015. Т. 5, № 4. С. 20-21.

3. Бойко Н.И. Простатилен - препарат предстательной железы Доктор. 2004. № 3. С. 73-75.

4. Державна Фармакопея України: в 3 т./ Державне підприємство «Український науковий фармакопейний центр якості лікарських засобів». 2-е вид. Доповнення 3. Харків, 2018. 416 с.

5. Гель ректальний для корекції простатиту та відновлення функції передміхурової залози: пат. 145632 Україна: МПК (2020.01) А61К 8/98, А61К 9/06, А61Р 15/08. № u 202004670; заявл.23.07.20; опубл. 28.12.20, Бюл. № 24.4 c.

DOI https://doi.org/10.30525/978-9934-26-182-4-28

\section{ОСОБЛИВОСТІ ТЕХНОЛОГІЧНОГО ПРОЦЕСУ ВИГОТОВЛЕННЯ НОВОГО ЗАСОБУ ДЛЯ ПРОФІЛАКТИКИ УСКЛАДНЕНЬ ЗА УМОВ ВАГІТНОСТІ}

\author{
Вишневська Л. I. \\ доктор фармацевтичних наук, професор, \\ завідувачка лабораторії аптечної технологї ліків \\ Національний фармацевтичний університет \\ Камишан А. C. \\ здобувач вищої освіти, 5 курс \\ спеціальність: 226 «Фармація, промислова фармація» \\ Начіональний фармачевтичний університет \\ м. Харків, Украӥна
}

Особливе занепокоєння викликає погіршення репродуктивного здоров'я жінок, яке проявляється в зростанні захворюваності серед вагітних, зниженні числа нормальних пологів і збільшенні відхилень розвитку плода. Відомо, що репродуктивна система жінки під час 
вагітності особливо чутлива до впливу негативних факторів будь-якого походження. Така підвищена чутливість у цей період сприяє забезпеченню захисту ембріонів від факторів зовнішнього середовища. Для плода організм матері є тим середовищем, в якому він розвивається. У зв'язку з цим в більшості випадків стан материнського організму відіграє провідну роль в етіології порушень розвитку плода, які призводять до збільшення частоти спадкових захворювань, вроджених вад і аномалій розвитку у новонароджених [1].

Отже, можна стверджувати, що від впливу різних соціальнобіологічних чинників на загальний стан здоров'я матері буде залежати в подальшому здоров'я новонародженого. Тому прогнозування ймовірності "поломки" функціональних систем i розробка адекватних заходів профілактики організму жінки за умов вагітності $є$ актуальною задачею медицини і фармації.

Для нівелювання пошкоджуючої дії чинників різної етіології на організм жінки нами запропоновано розробку профілактичного засобу на основі активних фармацевтичних інгредієнтів природного походження, а саме амінокислот - карнітину та гліцину. Серед їх основних фармакологічних ефектів відмічають універсальну антистресорну дію та підвищення адаптаційних можливостей організму за відсутності протипоказань і побічних ефектів у вагітних.

Сьогодні сучасна медицина приділяє велику увагу використанню препаратів у раціональній лікарській формі, тому враховуючи, що гліцин піддається пресистемному метаболізму у печінці і одразу не потрапляє до основного органу мішені - головного мозку, перспективним вважається розробка засобу у формі таблеток для застосування в ротовій порожнині (ородисперсних), у нашому випадку сублінгвальних таблеток.

Відомо, що окрім оптимально підібраного, науково обгрунтованого складу лікарських засобів, велике значення в досягненні їх максимального терапевтичного ефекту, забезпеченні стабільності та задовільних споживчих характеристик надається технології приготування [2].

Метою роботи було з'ясувати особливості технологічного процесу виготовлення нового засобу для профілактики ускладнень за умов вагітності.

Методи дослідження. Фізико-хімічні методи, фармако-технологічні випробування зразків порошкових композицій проводили вимірюванням об’єму певної маси проби порошку, просіяного крізь сито в градуйований циліндр $з$ та без механічного струшування (насипна густина, показник стисливості, коефіцієнт Гауснера), фіксуванням діаметра основи конусу стовпчика порошку (кут природного укосу), статистичні [3]. 


\section{Результати та їх обговорення.}

Сублінгвальні таблетки - тверді однодозові лікарські засоби для використання під язиком, відповідно для одержання системної дії. Їх готують пресуванням суміші порошків або гранулятів в таблетки відповідної форми залежно від передбачуваного застосування. При виробництві сублінгвальних таблеток мають бути вжиті відповідні заходи, які забезпечують необхідну механічну міцність і стійкість до роздавлювання і стирання [2].

У зв'язку з тим, що новий засіб містить дуже вологочутливу активну субстанцію-лівокарнітину гідрохлорид, метод прямого пресування у нашому випадку не $\epsilon$ прийнятним. Тому постало питання вивчення умов одержання сумішей для таблетування через грануляцію, використовуючи різні технологічні прийоми.

Грануляція необхідна для поліпшення технологічних властивостей таблеткової маси і запобігання іiі розшаровуванню. Вона забезпечує покращення текучості вихідних матеріалів, попереджує розшаровування мас, які таблетують, забезпечує рівномірну швидкість надходження маси в матрицю таблеткової машини, більшу точність дозування та рівномірний розподіл активного компоненту в суміші. Грануляція буває трьох типів, але на практиці обмежуються лише вологою.

Попередніми фармако-технологічними дослідженнями з урахуванням фізико-хімічних властивостей основних активних інгредієнтів в якості допоміжних компонентів сублінгвальних таблеток запропоновано використання манітолу та целюлози мікрокристалічної в ролі основних формоутворювачів, 3 додаванням дезінтегранта або розпушувача кросповідону-XL, ковзких речовин-аеросилу та магнію стеарата, зв'язуючого компонента - крохмалю прежелатинізованого, підсолоджувача та коригенту смаку - сахарину натрію. Контрольні зразки мас для таблетування одержували згідно наступних стадій: підготовка сировини (відважування), приготування розчину для зволоження, приготування вологого грануляту, сушка грануляту, суха грануляція, обпудрювання грануляту.

На етапі розробки нового засобу на основі лівокарнітину гідрохлориду та гліцину було одержано три дослідні суміші середньої маси форми 0,60 0,65 г, послідовність технологічних стадій була однаковою, відмінність набувала лише складова частина компонентів розчинів для зволоження та сухої суміші, яку в послідуючому зволожували. Приготування цих мас об’єднує той факт, що одну діючу речовину - гліцин уводили у сухому вигляді, а іншу (лівокарнітину гідрохлорид) додавали або у складі комбінованого водного розчину для зволоження з сахарином натрію або у 
порошкоподібному стані. Загальний вміст активних фармацевтичних інгредієнтів у ефективно терапевтичних дозах по 100 мг сумішей знаходився в межах 35-38 \%, відповідно доля основних наповнювачів становила $60 \%$.

Дослідні маси для таблетування піддавали фармако-технологічним випробуванням згідно методик ДФ України 2 вид. Встановлено, що насипна густина мас для таблетування знаходилася в діапазоні значень класу легких $<0,6$ г $/ \mathrm{cm}^{3}$. Параметри кута природного укосу дозволяють відносити їх до матеріалів з задовільною текучістю (36-40 град), показник стисловості знаходиться в межах значень, що відповідають за хорошу текучість (11-15 \%), коефіцієнт Гауснера наближується до показника, що вказує на дуже хорошу текучість $(1,00-1,11)$.

Але слід зазначити, якщо для свіжовиготовлених сумішей підібраного складу ми мали можливість вимірювати їх технологічні показники, то вже через 24 год зберігання маси набули небажаної вологості, тобто висока гігроскопічність лівокарнітину гідрохлориду знову не дозволила отримати суміші придатні для таблетування.

Тому запропоновано в масі для таблетування підвищити загальну частку наповнювачів до $85 \%$, при цьому дозування діючих речовин залишалося на рівні ефективних терапевтичних доз, середня маса на одну таблетку становила 1,5 г. Візуальне спостереження за масами протягом певного часу довело, що суміші мали задовільні вологосорбційні характеристики, тому виявилося можливим оцінити їх технологічні властивості відповідно [3], результати наведено в таблиці.

Таблиця

Технологічні характеристики маси для таблетування, $(\mathrm{X} \pm \mathrm{Sx}), \mathrm{n}=5$

\begin{tabular}{|c|c|c|c|c|}
\hline \multicolumn{5}{|c|}{ Показник } \\
\hline $\begin{array}{c}\text { Нусипна } \\
\text { гусина, } \\
\text { г/мл }\end{array}$ & $\begin{array}{c}\text { Густина після } \\
\text { усадки, } \\
\text { г/мл }\end{array}$ & $\begin{array}{c}\text { Показник } \\
\text { стисливості, } \\
\%\end{array}$ & $\begin{array}{c}\text { Коефіціснт } \\
\text { Гауснера }\end{array}$ & Текучість \\
\hline $0,554 \pm 0,010$ & $0,662 \pm 0,001$ & $4,5 \pm 1,6$ & $0,91 \pm 0,02$ & хороша \\
\hline
\end{tabular}

Дані таблиці свідчать, що показники, які відповідають за текучість порошкових композицій, знаходилися в межах значень, що характеризують їі як хорошу та дуже хорошу. Ці результати вказують, що гранулят, де активні речовини виявилися більш розведеними в суміші наповнювачів, не буде зависати в бункері таблеткової машини і не 
потребує для таблетування додаткового використання допоміжного устаткування.

Висновок. Для одержання нового засобу для профілактики ускладнень за умов вагітності у формі сублінгвальних таблеток запропоновано метод через грануляцію, зокрема вологу, який передбачає послідовне застосування діючих речовин - лівокарнітину гідрохлориду та гліцину в індивідуальних розчинах для зволоження сухих компонентів маси. Цей метод виявився найбільш приємним в технологічному плані, хоча і має ряд додаткових стадій загального процесу одержання таблеток.

\section{Література:}

1. Лепьошкіна Т.Р. Навколишнє середовище i репродуктивне здоров'я. Довкілля та здоров'я. 2004. №1. С. 76-80.

2. Вронська Л. В., Демчук М. Б., Гордієнко О. І., Грошовий Т. А. Сучасний стан створення, виробництва та дослідження таблетованих лікарських препаратів. Фармачевт. часопис. 2014. № 3. С. 105-112.

3. Державна Фармакопея України 2-е вид. Доповнення 4. Харків. $2020.600 \mathrm{c}$. 